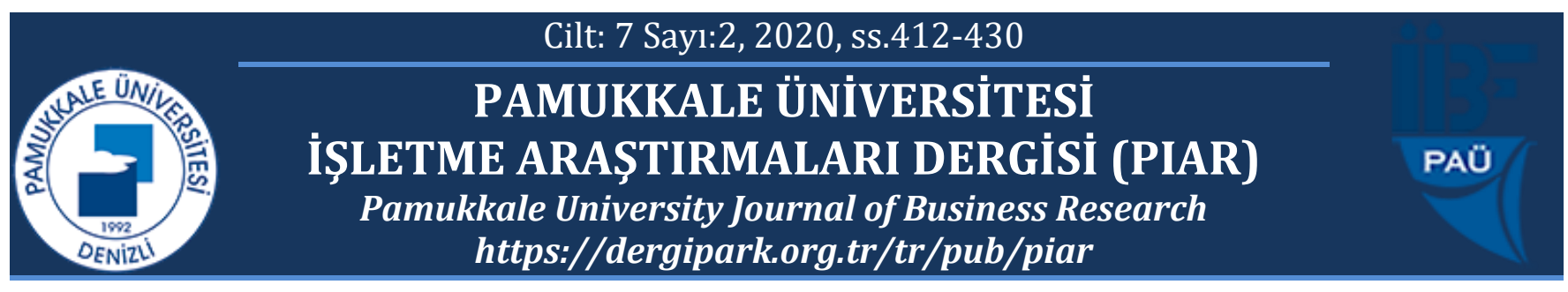

\title{
Bir Sağlık İşletmesinin Atık Yönetiminde Tersine Lojistik Süreçleri ${ }^{*}$
}

\section{Reverse Logistics Processes of A Healthcare Business in Waste Management}

\section{Mustafa BAYHAN ${ }^{*}$}

\section{Müge GÖRÜCÜ²}

\footnotetext{
${ }^{1}$ Pamukkale Üniversitesi, İ̈BF, İşletme Bölümü, mbayhan@pau.edu.tr, https://orcid.org/0000-0001-5793-5390

${ }^{2}$ Tekden Hastanesi Denizli, mugegorucu00@gmail.com, https://orcid.org/0000-0002-6967-4869

* Yazışılan Yazar/Corresponding author
}

Makale Geliş/Received: 23.11.2020

Öz

Son yillarda hammadde kaynaklarmin azalmaya ve tükenmeye başlaması, çevresel kirliliğin ve atık sahalarmın hızla artış göstermesi ile birlikte, insan ve çevre güvenliği, işletmeler için çok önemli bir öncelik haline gelmeye başlamıştır. Kaynakların sınırlı olması, atıkların kaynağında ayrıştırılması ve uygun depolama alanlarının yetersizliği, çevre ve canlı sağhlŏ̆ına zararl tehlikeli maddelerin kullanim ve bertarafi ile ilgili personel eğitimlerinin yetersizliği gibi nedenlerden dolayı, özellikle sağlık kurumlarında bu konunun dikkatle ele alınmasını gündeme getirmiştir. Bu çalışma, tersine lojistik uygulamalarmm hastane atık yönetimine olan etkilerini ortaya koymak amacıyla yapılmıştır. Araştırma kapsamında, tersine lojistik ve atık yönetim süreçleri incelenerek, bu sürecin olası etkileri ortaya koyulmaya çalışılmıştır. Araştırma Denizli ilinde faaliyet gösteren özel bir hastanede yapılmıştır. Toplanan veriler araştırma sonunda sunulmuş, elde edilen veriler değerlendirilmiştir.

Anahtar kelimeler: Tersine Lojistik, Hastane Atık Yönetimi, Tekrar Kullanma, Geri Dönüşüm

JEL kodları: M10,Q53, I10
Makale Kabul/Accepted: 18.12.2020

\begin{abstract}
In recent years, with the decrease in raw material resources and depletion and the rapid increase in environmental pollution and waste sites, natural environment has become a competitive element among enterprises. As a result of limited resources, inadequate waste storage and disposal areas, personnel trainings related to hazardous materials use and disposal, and incentives for the use of renewable energy resources in a narrow scope, the concept of "Reverse Logistics" has been brought to the agenda in health institutions. This study was carried out to determine the effects of reverse logistics applications on hospital waste management. In the scope of the research, reverse logistics and waste management processes were examined and possible effects of this process were tried to be revealed. The study was conducted in a private hospital in Denizli. The data collected were presented at the end of the research and the data obtained were evaluated.
\end{abstract}

Keywords: Reverse Logistics, Hospital Waste Management, Reuse, Recycle

JEL codes: M10,Q53, I10

\footnotetext{
* Bu çalışma, PAÜ.Sosyal Bilimler Enstitüsü, İşletme Anabilim Dalı, Üretim Yönetimi ve Pazarlama Bilim Dalı öğrencisi Müge GÖRÜCÜ tarafından Dr. Öğr. Üyesi Mustafa BAYHAN yönetiminde hazırlanan "Bir Sağlık İşletmesinde Yeşil Tedarik Zinciri Yönetimi Süreçlerinin Değerlendirilmesi” başlıklı tezden üretilmiştir.
} 


\section{GİRIŞ}

Son yıllarda kaynak tüketiminin artması ile birlikte hammadde kaynaklarının azalmaya ve tükenmeye başlaması, çevresel kirliliğin ve atık sahalarının hızla artış göstermesi ile birlikte doğal çevre işletmeler arasında bir rekabet unsuru haline gelmeye başlamıştır. Hastanelerde kullanılan malzemelerin çeşitli ve çok sayıda olduğu ve bu duruma paralel olarak su, enerji gibi kaynak tüketiminin yoğun, tehlikeli, kimyasal ve enfekte atık çıtı miktarının fazla olduğu işletmelerdir. Fakat kaynakların kıt olması, atık depolama ve imha alanlarının yetersiz olması, tehlikeli madde kullanımı ile ilgili personel eğitimlerinin yetersizliği ve yenilenebilir enerji kaynakları kullanımı için teşviklerin az olması sağlık kurumlarında “Tersine Lojistik" kavramını gündeme getirmiştir (Terekli vd., 2013:38).

Hastanelerde "Tersine Lojistik Yönetimi ve Faaliyetleri” ile kaynak kullanımına alternatifler üretilerek satın alınan malzemelerin, enerji ve su gibi doğal kaynakların daha etkin ve verimli kullanılmasını sağlamak ve bu doğrultuda atıkların kaynağında azalmasını, önlenmesini, tekrar kullanımını ve geri dönüşümü sağlanarak hastanelerin çevreye verdiği zararın ve kirliliğin önüne geçilmesi amaçlanmaktadır.

Araştırma kapsamında, hastanenin "Hastane Atık Yönetiminde Tersine Lojistik Süreçleri" incelenmiştir. Toplanan veriler araştırma sonunda sunulmuş, elde edilen veriler değerlendirilmiştir. Değerlendirmeler sonucunda, mevcut sürece ilişkin durum tespiti yapılarak insan ve çevre açısından tehlike oluşturacak durumlar tespit edilmiş, bu süreçte dikkat edilmesi gereken hususlar ortaya konulmuş ve bu süreçte görev yapan personelin farkındalıklarının artırılması vb. amaçlarına yönelik yapılacak çalışmalara bir temel oluşturulmaya çalışılarak, hastane işletmeleri için önerilere yer verilmiştir.

\section{TERSİNE LOJISTTIK}

Küreselleşmenin hız kazanması ile birlikte işletmeler uluslararası pazarda rekabet etmek zorunda kalmıştır ve küresel rekabet baskısına dayanmayan birçok işletme pazardan çekilerek, iflas etmiştir. Bu duruma benzer birçok ekonomik, sosyolojik ve çevreyle ilgili sebepler tüketiciden üreticiye doğru olan geleneksel akışın aksi yönünde bir akışın oluşmasına neden olmuştur. Bu akışa; “Tersine Lojistik” adı verilmiştir. Lojistik faaliyetler içerisinde yer alan tersine lojistik kavramı, son y1llarda lojistik faaliyetlere farklı bir boyut kazandırmıştır.

Literatürde tersine lojistik kavramı ile ilgili birçok tanım yer almaktadır. Bunlardan bazıları;

Tersine lojistik ile ilgili ilk tanımları yapan Lambert ve Stock (1981) tersine lojistiği; “Tek yöndeki ürün gönderiminin (ileri lojistik) önemi sebebi ile tek yönlü bir yolda yanlış yönde gitmek" olarak tanımlanmıştır (Rogers ve Tibben-Lembke, 2001).

Fleischmann'ın göre tersine lojistik; “Geleneksel tedarik zincirinin aksi yönde malzemenin yeniden kazanılması ya da uygun bir yöntemle yok edilmesi amacıyla, ikincil malzeme depolarının, malzeme akışının ve bilginin verimli planlanması, uygulanması kontrol edilmesi işlemleridir"' (Fleischmann ve diğerleri, 2001: 157).

1990'lı yıllarda Lojistik Yönetim Konseyi, Tersine Lojistik'le ilgili bilinen ilk tanımını yapmıştır. Konseye göre, Tersine Lojistik kavramı; “Envanter süreçleri, nihai ürünler, kullanılmış malzemeler ve ilgili bilgilerin tüketim noktasından, üretim (başlangıç) noktasına 
tekrar değer kazanma veya düzgün bir şekilde elden çıkarma amacıyla ağ yapısını planlama, yürütme ve kontrol etme sürecidir (www.supply-chain.org)".

Tersine lojistik artık kullanılmayan ürünlerden, yeniden kullanımı sağlanan ürüne kadar olan tüm lojistik faaliyetleri içine alan bir süreçtir. Buna göre tersine lojistiğin dağıtım açısından ilk faaliyeti; kullanılmış ürünlerin son tüketiciden, üreticiye doğru taşınmasını gerçekleştirmektir. İkinci faaliyeti ise; geri dönen ürünlerin üreticiler tarafından tekrardan ürün haline getirilmesidir (Fleischmann ve diğerleri, 1997: 2). Tersine lojistiği; ileri lojistiğin tersine doğru süreçleri olarak zihnimizde canlandırabiliriz. Tersine lojistik en çok taşıma ve stok yönetim faaliyetlerini içine alarak müşterilerden geden ürünlerin geri dönüşümüne odaklanmaktadır (Eltayeb, Zailani ve Ramayah, 2010: 4). Şekil 1'de tedarikçilerden müşterilere doğru olan ileri akışı ve müşterilerden tedarikçilere doğru olan tersine akışı göstermektedir (Fleischmann ve diğerleri, 1997: 5).

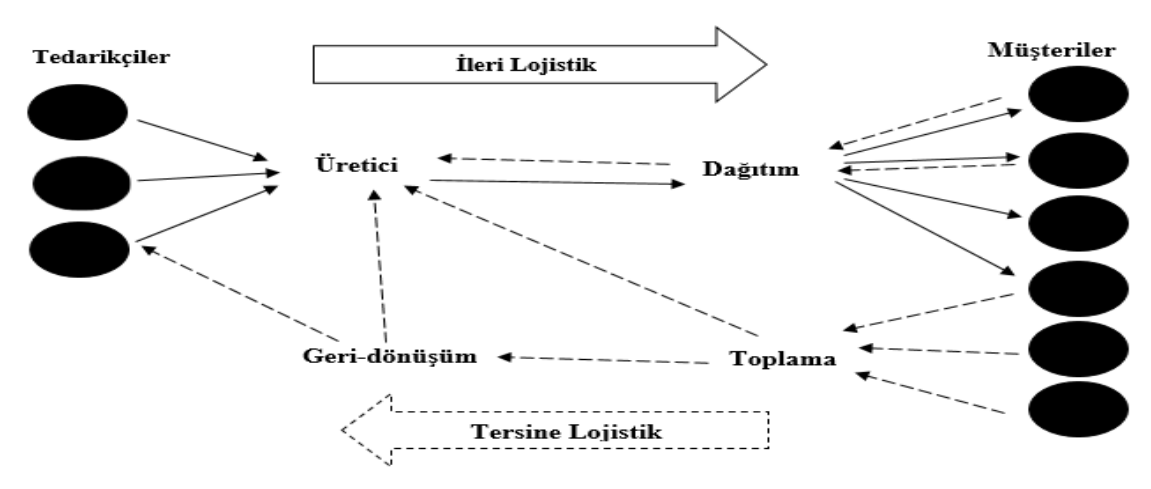

Şekil 1. İleri Lojistik ve Tersine Lojistik Arasındaki İlişki

(Kaynak: Fleischmann vd., 1997: 5)

Şekil 1'de yer alan tersine lojistik faaliyetler sistemden ayrı olarak düşünülmemelidir. Bu çerçeve içerisindeki tüm faaliyetler; ileri ve tersine lojistik olarak kabul edilmektedir ve lojistik faaliyetlerin sistemli bir şekilde çalışmaları sağlanmaktadır. Değişik lojistik faaliyetler sonucunda oluşan üretim girdileri ile üretim sonrasında oluşan ürünün, nihai tüketiciye taşınmasına kadar gerçekleşen tüm lojistik faaliyetlere ileri lojistik adı verilmektedir (TibbenLembke ve Rogers, 2002: 275).

Tersine lojistik ağında, ileri lojistik ağının elemanlarına ek olarak lojistik firmaları, atık arazileri, ikincil pazarlar ve buna benzer ek birimler olmak üzere daha fazla birim bulunmaktadır. Ağdaki bu bölümler için; geçmişte belirlenen bir talep olmadığı için kapasiteleri değişik kısıtlarla sınırlandırılmış olup hepsi farklı özellikler göstermektedir. Atık arazilerine işletmelerin göndereceği atık miktarları hükümet tarafından sınırlandırılmaktadır. "Ürün ve ya ürünler ne zaman geri döner?", “Geriye dönen ürün veya ürünler nereye taşınmalı?", "İşletmeler kârlarını maksimize etmek için hangi stratejiyi kullanmalı?" bu ve bu gibi sorular tersine lojistik ağ 1 tasarımında araştırmacıların ilgisini çeken sorulardır (Demirel ve Gökçen, 2008: 904). 
Ürünlerin geri dönüştürülmesine yardım eden tersine lojistik kavramı "Çevreye Duyarlı Lojistik" olarak da adlandırılmaktadır(Erkayman, 2007: 21). Bu sebeple; tersine lojistik kavramı da geri dönüşüm, yeniden üretim, yeniden satış, yeniden kullanım ya da imha için ürünleri ve atıkları işletmelerde geri kazanma süreci olarak da ifade edilmektedir (Johnson, 1998: 217).

Tersine lojistik sürecinde uygulanan faaliyetler; yeniden kullanım/ tamir etme, yeniden üretim / parçaları sökme demonte etme ve geri dönüşümden oluşmaktadır.

\section{TERSINE LOJISTIK FAALIYYETLERDE HASTANE ATIKLARININ DEĞERLENDİIILMESİ}

Tersine lojistik faaliyetlerde hastane atıklarının değerlendirilmesi; Hastane atıklarının sınıflandırılması, hastanelerde entegre atık yönetimi, geri kazanım, atıkların muamele edilmesi ve nihai bertaraf faaliyetlerinden oluşmaktadır.

\subsection{Hastane Atıklarının Sınıflandırılması}

Ülkemizde hastanelerden kaynaklanan atıklar; tıbbi atıklar, tehlikeli atıklar, evsel nitelikli atıklar ve radyoaktif atıklar olarak sinıflandırılmaktadır (TAKY, 2017).

Evsel nitelikli atıklar; genel ve ambalaj atıkları olarak ikiye ayrılmaktadır. Genel atıklar; temizlik hizmetleri, yemekhane atıkları gibi enfekte olmayan tıbbi merkezlerden kaynaklanan atıklardır. Ambalaj atıkları ise; ofis, yemekhane, depo gibi alanlardan kaynaklanan tekrar kullanılabilir, geri kazanılabilir atıklar: kâğıt, karton, mukavva, plastik, cam, metal vb. atıklardan oluşmaktadır (İSTAÇ ${ }^{1}$ ).

Tıbbi Atıklar; enfeksiyöz atıklar, patolojik atıklar ve kesici delici atıklardan oluşmaktadır. Enfeksiyöz Atıklar; taşınması ve imhası özel uygulama gerektiren atıklardır. Başlıca kaynakları; mikrobiyolojik laboratuvar atıkları, kan kan ürünleri ve bunlarla kontamine olmuş nesneler, kullanılmış ameliyat giysileri, diyaliz atıkları, karantina atıkları, bakterivirüs içeren hava filtreleri, ve enfekte deney hayvanı leşleri, organ parçaları, kanı ve bunlarla temas eden tüm nesnelerdir. Patolojik Atıklar; Anatomik atık dokular, organ ve vücut parçaları ile ameliyat, otopsi vb. tıbbi müdahale esnasında ortaya çıkan vücut sıvıları; ameliyathaneler, morg, otopsi, adli tıp gibi yerlerden kaynaklanan vücut parçaları, organik parçalar, plasenta, kesik uzuvlar vb., biyolojik deneylerde kullanılan kobay leşlerinden oluşmaktadır. Kesici Delici Atıklar; Batma, sıyrık gibi yaralanmalara neden olabilecek enjektör iğnesi gibi iğne içeren kesiciler, bisturi, lam-lamel gibi atıklardan oluşmaktadır.

Tehlikeli Atıklar; kimyasal özelliklerinden dolayı özel işleme tabi olacak atıklar: Tehlikeli kimyasallar, sitotoksik ve sitostatik ilaçlar, genotoksik atıklar, farmasötik atıklar, ağır metal içeren atıklar ve basınçlı kaplardır.

Radyoaktif Atıklar; Türkiye Atom Enerjisi Kurumu mevzuatı hükümlerine göre toplanıp uzaklaştırılan atıklardır.

\subsection{Veri Toplama Araçlarının Geçerlik ve Güvenilirliğine İlişkin Bulgular}

Hastaneler, hastaları iyileştirip insanların sağlık problemlerini azaltmaya yönelik faaliyetlerini gerçekleştirirken atık üretirler. Üretilen bu tıbbi ve tehlikeli atıkların kontrolsüz bir şekilde yok edilmesi; doğal çevrenin kirlenmesine ve ekolojik dengenin bozulmasına 
neden olmaktadır. Hastanelerin geçici atık depolama alanlarında yaşanılan atık depolama sıkıntıları, tüketicilerin artan çevre bilinci ve hastanelerde yeşil faaliyetlerin etkili olmaya başlaması atık yönetimini de zorunlu hale getirmiştir. Oluşan atıkların yok edilmesi veya atık minimizasyonu sağlanmak için atık yönetiminde çeşitli yöntemler kullanılmaktadır. Bu yöntemlerden biri de atık yönetim hiyerarşisidir. Atık yönetim hiyerarşisinde aşağıdan yukarıya çıkıldıkça sürdürülebilirlik ve sağlıklı çevre seçenekleri artış göstermektedir. Hastanelerin faaliyetleri sonrasında ortaya çıkan atıkların yönetimi Şekil 2' de verilen Atık Hiyerarşi olarak tanımlanan sıralama çerçevesinde sağlanmaktadır.

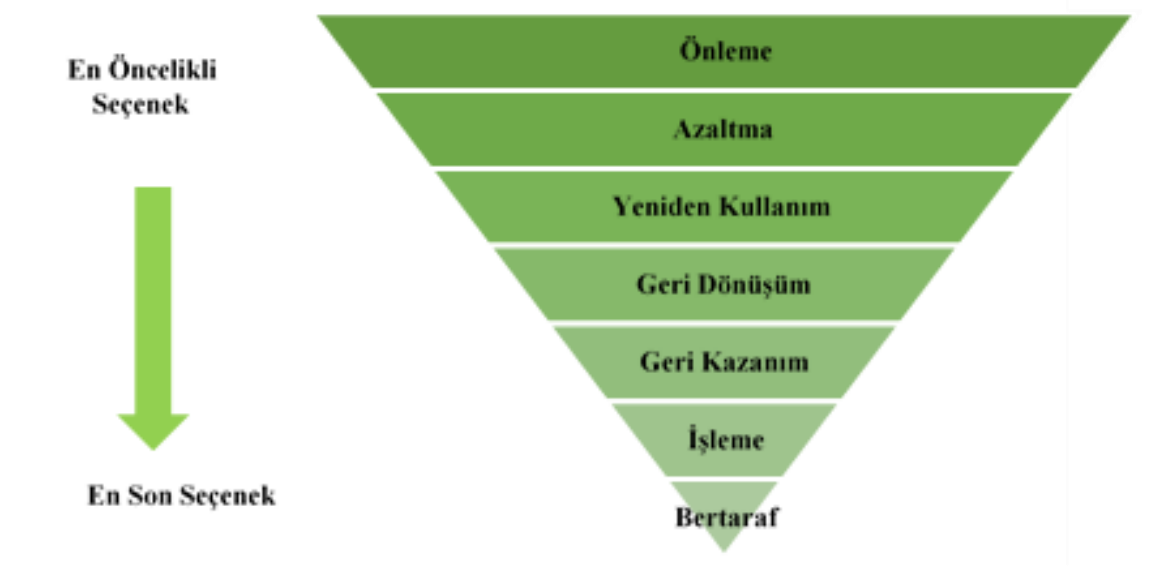

Şekil 2. Entegre Atık Yönetimi Hiyerarşisi

(Kaynak: Parker, 2010: 143)

Hastanelerde üretilen atık miktarlarını azaltmak amacıyla atıklar kaçınılması gereken atıklar, yeniden kullanılması mümkün olan atıklar, geri dönüşümü gerçekleşen atıklar ve yok edilmesi gereken atıklar şeklinde sınıflandırılmıştır. Bu atık türleri şunlardır (Terekli, Özkan ve Bayin, 2013: 43);

"Kaçınılması Gereken Atıklar: Kullandığımız tüm ürünlerin çevreye duyarlılık açısından değerlendirilmesi gerekir. Yapılan değerlendirmeler sonucunda, kaçınılması gereken ürünler tespit edilmektedir ve değerlendirme sonucunda tehlikeli olan hiç kullanılmaması gereken ürünler daha az tehlikeli ürünlerin kullanılması sağlanabilmektedir. Örneğin, hastanelerde tek kullanımlık galoşların kullanımının azaltılması veya hiç kullanılmaması sağlanabilir. Birçok araştırmacı; devamlı hijyen için galoş kullanımının gerekli olmadığını savunmaktadır. Aynı şekilde hastaneler acil ihtiyaçlarını karşılayacak kadar kimyasal ürün satın almalıdır. Yeniden Kullanılabilen Atıklar: Bazı hastane malzemelerinin, dezenfekte edilerek gerektiğinde sterilize edilerek yeniden kullanılabilmesi mümkündür. Yapılan bazı araştırmalar, hastanelerde kullanılan redon ve toraks şişeleri ile vakum sistemlerinin yeniden kullanılması ile yaklaşık \%50 atık tasarruf yapılabileceğini göstermiştir. Geri Dönüşümü Mümkün Olan Atıklar: kâğıt, karton, cam, floresan tüpler, kullanılan bazı çözücüler ve bazı radyoaktif atıkların geri dönüşümü mümkün olabilmektedir. Yok Edilmesi Gereken Atıklar: Hastanelerde oluşan bulaşıcı atıklar, kimyasal atıklar, radyoaktif atıklar, civa termometre gibi atık türleri özel olarak imha edilmeyi gerektirir. Bu atıklar yerel yönetmeliklere uygun bir şekilde yok edilmelidir." (Terekli, Özkan ve Bayın, 2013: 43). 


\subsubsection{Atık Oluşumunun Önlenmesi veya Azaltılması}

Atık Hiyerarşisi'ne göre; en önemli adım atığın oluşumundan önce atığın kaynağında önlenmesi veya azaltılmasıdır. Atık oluşumunun önlenmesi için ürünlerin kullanım ömürlerinin uzatılması ve ürünlerin yeniden kullanım faaliyetlerinin yaygınlaştırılması gerekir. Ancak, her ürünün yeniden kullanımı ve kullanım ömrünü uzatılması mümkün olmadığı için gereksiz ürün tüketiminin önüne geçilerek atıkların kaynağında azaltılması amaçlanmaktadır. Hastanelerde tek kullanımlık ve geri dönüşümü olmayan ürünlerin kullanılması ve satın alınması ile atık üretimi oluşmaktadır (Laustsen, 2007).

Hastanelerde tek kullanımlık yatak çarşaflarının ve kâğıt havluların aşırı kullanımı, tıbbi malzemelerin gereğinden fazla paketlenmesi atık üretimine katkıda bulunmaktadır (Laustsen, 2007). Günümüzde hastane işletmeleri atıklarını çevreye zarar vermeden yok etme konusunda başarılı olamamaktadır. Birçok hastane enfekte atıkların kaynağında ayrıştırılmasına dikkat etmemekte ve bu atıklar evsel nitelikli çöp depolama alanına boşaltılmaktadır. Literatürde tıbbi atıkların bertaraf edilmesiyle ilgili yapılan çalışmalara göre; tıbbi atıkların \%60'1 yakma, \%37'si buhar sterilizasyonu ve \%5'i diğer yöntemlerle yok edilmektedir (Lee, Ellenbecker ve Moure-Ersaso, 2004).

Tıbbi atıkların yakılması sonucunda insan ve çevre sağlığına zarar verici kül, metan gazı, civa ve dioksin gibi maddelerin ortaya çıkmaktadır (Ferraz, Barcelos ve Pontes, 2000; Fritsky, Kumm ve Wilken 2001; Lee ve diğerleri, 2004).

Tıbbi atıkların yok edilmesinde yakma faaliyetinin yerine atıkların insan ve çevre sağlığına daha az zarar veren otoklav, radyodalga, mikrodalga fırınları, elektroteknoloji, buhar detoksifikasyonu ve buhar sterilizasyonu yöntemleri tercih edilmelidir. Yapılan çalışmalar, hastanelerin tıbbi atıklarını sınıflandırma yöntemleri geliştirerek tıbbi atıkların özelliklerine göre en etkin arıtma ve yok etme yöntemleri kullandığında toplam maliyeti önemli oranda azaltabildiklerini göstermektedir (Lee ve diğerleri, 2004).

Hastanelerde atıkların toplanma ve ambalajlanma sırasında birbiri ile teması atık miktarının artmasına neden olmaktadır. Geri dönüşümü ve yeniden kullanımı mümkün olan ambalaj ve cam atıkların, tıbbi ve enfekte atıklar ile aynı yerde toplanması atık miktarının artmasına neden olur. Bu sebeple; atıkların toplanması ve ambalajlanması yönetmeliklerde belirtilen şekilde gerçekleştirilmesi gerekir. Atıkların kaynağında ayırımına dikkat edilmesi, atıkların belirtilen renkteki torbalara konulması, tehlikeli ve enfekte atıkların insan ve çevre sağlı̆̆ına vereceği zararların önüne geçmektedir.

Ülkemizde “Doğayı İyileştiren Atık Yönetim Sistemi ve Uygulamaları Projesi” ile Abdi İbrahim İlaç Firması, sağlık sektöründeki atık oluşumunun önlenmesi veya azaltılması destekleyen kuruşlardan biri olmuştur. Firmanın 2012-2015 yılları arasında üretim miktarı \%1 olmasına rağmen etkin atık yönetim ile geri dönüştürülebilir atıklarını \%32, tehlikeli atıklarını ise \%15 oranında azalmıştır ve atık su arıtma tesisinde de MBR (membran bio reaktör) teknolojisinin kullanılması çamur atığını sıfıra indirmiştir.

\subsubsection{Yeniden Kullanma}

Atık Hiyerarşisi'nde yeniden kullanım ile üretilen atıkların başka bir ürünün oluşumunda kullanılması amaçlanmaktadır. 


\subsubsection{Geri Dönüşüm}

Atık Hiyerarşisi'nde geri dönüşüm cam, metal, karton, plastik ve ambalaj gibi atıkların fiziksel ve kimyasal işlemlere tabi tutularak yeniden kullanılabilir hale getirilmesi faaliyetidir.

\subsubsection{Hastane Atıklarının Geri Dönüş Aşamaları}

Hastane atıkların geri dönüşümünde şu aşamalar izlenmektedir (Kayar, 2015: 48):

1. Aşama; hastanelerde çeşitli nedenlerle kullanılan ürünler atık çeşidine göre konteynerlerde toplanarak lisanslı firmalara ve belediyelere teslim edilir.

2. Aşama; toplanan atıklar özelliklerine göre ayrılırlar.

3. Aşama; geri kazanabilir atıklar uygun geri kazanım yöntemi ile tekrar kullanılabilir hale getirilirler.

4. Aşama; geri kazanılması mümkün olmayan atıklar yakma veya gömme yoluyla çevreye zarar verilmeden imha edilir.

5. Aşama; geri kazanılan ürünler pazarlarda yeniden satışa sunulur.

\subsubsection{Hastane Atıklarının Geri Dönüşümünde Kullanılan Yöntemler}

Hastane atıklarına tersine lojistikte geri dönüşüm faaliyetleri uygulanırken kullanılan yöntemler; kimyasal biyolojik ve fiziksel ayrıştırma yöntemleri olmak üzere üçe ayrılmaktadır (Erdal, Görçün ve Saygılı 2010: 492-493):

Kimyasal Ayrıştırma Yöntemleri: Bu teknikte atıklara kimyasal işlemler uygulanarak maddelerin ayrışması sağlanır. Genellikle Atıkların filtrelenmesinde uygulanan bu yöntemde tepkimelere ve kimyasal özelliklere bağlı olarak işlemler değişiklik göstermektedir.

Biyolojik Ayrıştırma Yöntemleri: Ayrıştırılan atıklar, mantar gibi organizmalar yardımıyla parçalanarak yeniden sanayiye gönderilmektedir. Ayrıştırılması mümkün olmayan, ekonomik açıdan verimlilik sağlamayan atıklar ısıl yöntemler ile yakılarak yok edilmektedir.

Fiziksel Ayrıştırma Yöntemleri: Bu yöntem de büyük boyutlardaki parçaları tutmak için güçlü çekim kuvvetine sahip bir madde kullanılmaktadır. Ayırma işlemi ise yerçekimi gibi elektrostatik kuvvetler kullanılarak yapılır ve genelde otomotiv lojistiğinde uygulanmaktadır.

\subsubsection{Geri Kazanım}

Herhangi bir tesiste kullanılan maddelerin yerine ikame edilmek üzere atıkların faydalı bir amaç için kullanıma hazır hale getirilmesinde yer alan ve listelenen işlemleri ifade eder (Öktem, 2016: 139). Atıklardan enerji geri kazanım, geri dönüştürülmesi mümkün olmayan atık malzemelerden; yakma, gazlaştırma, piroliz, havasız arıtma gibi uygun süreçler yoluyla atıkların 1sıya, elektriğe veya yakıta dönüştürülerek kullanılmaması doğal kaynakların korunmasına katkıda bulunmaktadır. ${ }^{2}$ 


\subsubsection{Atıkların Muamele Edilmesi ve Nihai Bertaraf}

Geri kazanımı veya geri dönüşümü mümkün olmayan atıklar bertaraf edilmektedir. Tıbbi ve tehlikeli atıkların nihai bertaraf edilmesindeki amaç, atıkların tehlikeli olmayan maddelere dönüştürülerek insan ve çevre sağlığının korunmasıdır (Kokulu, 2001: 6; Baylan, 2009: 20). Tıbbi atıkların bertaraf edilmesi için kullanılan yöntemler; kimyasal dezenfeksiyon, otoklavlama, mikrodalga, düzenli depolama, mikrodalga radyasyon ve yakmadır (WHO, 1998). Ülkemizde atık bertafında yaygın olarak düzenli depolama ve yakma yöntemi kullanılmaktadır. En pahalı yöntem olarak bilinen yakma yöntemi atıkların yakılması nihai atık miktarını en fazla oranda azaltan ve enerji üretimi gibi önemli bir geri dönüşü sağlayan bir yöntem olarak bilinmektedir (Gündüzalp ve Güven, 2016: 5). Günümüzde atıkların çeşitlerine göre; atıkların yönetimi ve bertarfına ilişkin uygulamalar ve yaptırımlar yönetmelikler doğrultusunda açıklanmıştır. Ülkemizde tıbbi atıklar; yakma işlemi kullanılmadan, sterilizasyon işlemi ile sterilize edilmektedir. Sterilize edilen tıbbi atıklar, evsel atık niteliği kazanarak steril atık parçalama ünitesinde parçalanmakta ve parçalanan atıklar düzenli depolama sahasında bertaraf edilmektedir. Türkiye İstatistik Kurumu (TÜIK) 2016 yılı Atık Bertaraf ve Geri Kazanım Tesisleri İstatistikleri Tablo 1'de ayrıntılı şekilde verilmiştir.

Tablo 1: Atık Bertaraf ve Geri Kazanım Tesisleri İstatistikleri, 2014-2016

\begin{tabular}{|c|c|c|c|c|}
\hline \multicolumn{3}{|l|}{2014} & \multicolumn{2}{|r|}{2016} \\
\hline \multirow[t]{2}{*}{ Atık Bertaraf ve Geri Kazanım Tesisleri } & $\begin{array}{l}\text { Tesis } \\
\text { Sayisı }\end{array}$ & $\begin{array}{l}\text { İşlem Gören Atık } \\
\text { Miktarı (Ton) }\end{array}$ & $\begin{array}{l}\text { Tesis } \\
\text { Sayıs1 }\end{array}$ & $\begin{array}{l}\text { İşlem Gören Atık } \\
\text { Miktarı (Ton) }\end{array}$ \\
\hline & 985 & 61048878 & 1698 & 77208662 \\
\hline Atık Bertaraf Tesisleri & 117 & 41324637 & 140 & 44125262 \\
\hline Düzenli Depolama tesisi & 113 & 41281755 & 134 & 43815135 \\
\hline Yakma tesisi & 4 & 42882 & 6 & 310127 \\
\hline Atık Geri Kazanım Tesisi & 868 & 19724241 & 1558 & 33083400 \\
\hline Kom-post Tesisi & 4 & 19724241 & 7 & 140467 \\
\hline Beraber yakma (ko-insinerasyon) Tesisi & 39 & 532343 & 35 & 738908 \\
\hline Diğer geri kazanım tesisleri* & 825 & 19097879 & 1516 & 32204025 \\
\hline
\end{tabular}

(Kaynak: Türkiye İstatistik Kurumu (TÜIKK), 2017)

2017 yılı TÜIKK verilerine göre; ülkemizde 2016 yılında 140 atık bertaraf tesisi ve 1558 geri kazanım tesisi olmak üzere toplam 1698 tesisin faaliyet gösterdiği tespit edilmiştir. Toplam kapasitesi 834 milyon m3 olarak tespit edilen 134 düzenli depolama tesisinde, 6 milyon tonu tehlikeli olmak üzere 44 milyon ton atık bertaraf edilmiştir. Toplam kapasitesi 644 bin ton/y1 olan, 6 yakma tesisinde 63 bin ton tehlikeli ve 248 bin ton tehlikesiz olmak üzere toplam 310 bin ton atık bertaraf edilmiştir. Toplam kapasitesi 424 bin ton/yıl olan 7 kompost tesisinde 140 bin ton atık işlem görmüş ve 20 bin ton kompost üretilmiştir. Ayrıca atık geri kazanımı lisanslı 35 beraber yakma (ko-insinerasyon) tesisinde 739 bin ton atık yakılarak enerji geri kazanımı gerçekleştirilmiştir. Lisanslı diğer 1516 atık geri kazanım tesisinde ise toplam 32 milyon ton metal, plastik, kağıt, mineral vb. atık geri kazanılmıştır Türkiye İstatistik Kurumu (TÜİK), 2017. 


\section{ARAŞTIRMA}

$\mathrm{Bu}$ bölümde; araştırma konusunun literatür incelemesi yapılarak araştırmada kullanılan yöntem ayrıntılı bir şekilde anlatılmış olup, araştırma kapsamında elde edilen bulgular ayrıntılı bir şekilde sunulmuş ve elde edilen bulgular değerlendirilmiştir.

\subsection{Araştırma Konusunun Literatür İncelemesi}

Çalışmanın bu bölümde araştırma konusu olan "Tersine Lojistik" "Atık Yönetimi" ve "Tersine Lojistik Faaliyetleri" hakkında daha önceden yapılmış çalışmalar incelenmiştir. Konuyla ilgili literatür incelendiğinde;

Dündar (2010), “Hastane Atıklarının Yönetiminde Geri Kazanılabilir Atık Miktarlarının Tespiti ve Ekonomik Değeri Ankara Örneği" adlı çalışmada; ülkemizdeki sağlık kuruluşlarından kaynaklanan tıbbi atıkların bileşenleri, miktarları, Ankara'daki hastaneler ölçeğinde incelenerek; bu bileşenler içindeki geri kazanılabilir atık miktarının ve ekonomik değerinin tespit edilmesi amaçlamıştır. Çalışma sonucunda; ankete katılan hastanelerde Tıbbi Atıklar Kontrol Yönetmelik maddelerinin genelde uygulandığı fakat özelde eksik ve geliştirilmeye yönelik uygulamaların olduğu saptanmış ve geri kazanılabilir atıklar noktasında hastanelerde idari açıdan bilinç düzeyini yükseltmek için belli periyotlarda eğitim verilerek konunun ekonomik değerinin kavranması sağlanması gerektiği sonucuna ulaşmıştır.

Özkan, Bayın ve Yeşilaydın (2015) “Sağlık Kurumlarında Sürdürülebilir Atık Yönetimi” adlı çalışmalarında; çevre kirliliği ve kontrolü kapsamında önemli bir rol oynayan sağlık kurumlarındaki atık yönetimi hakkında bilgi vermek; sürdürülebilir yönetim çerçevesinde atık yönetimi ile ilgili çalışmalara ve uygulamalara yer vermeyi amaçlamışlardır. Çalışma sonucunda; Türkiye' deki mevcut atık yönetimi incelenmiş, sürdürülebilir tıbbi atık yönetimi

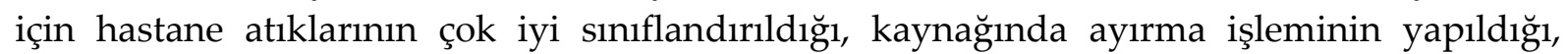
standartların getirildiği ve enfekte atıkların işlemden geçirilecek zararsız hale getirildiği bir bütüncül atık yönetim stratejisi benimsenmesi ve etkin bir denetim ve eğitim sürecinin olması sonucuna varılmıştır.

Ege ve Budak (2012), “Adana İli Tıbbi Atık Yönetimi; Sorunlar ve Çözüm Önerileri” adlı çalışmalarında; Adana kentinde tıbbi atık yönetimini incelemek, karşılaşılan problemleri belirlemek ve çözüm önerileri geliştirmeyi amaçlamışlardır. Yapılan çalışmada Adana kentinde üretilen tıbbi atıkların mevcut durumda nasıl yönetildiği tespit edilerek değerlendirilmiştir ve değerlendirme sonucunda Adana kentinde oluşan tıbbi atıkların bertarafı için en uygun yöntem olarak buharla sterilizasyon sonrasında düzenli depolama olduğu sonucuna ulaşılmıştır.

Kaya (2016), "Diş Tedavi Merkezlerinde Tıbbi Atık Yönetimi” adlı çalışmasında; diş tedavi merkezleri ve hastanelerinde, atık yönetimi ve atık yönetimine ilişkin sağlık çalışanlarının bilgi ve tutumlarını, merkezlerin duruma ilişkin uygulamalarını inceleyerek, tehlikeli ve tıbbi atıkların çevreye zarar vermemesi için diş tedavileri bittiğinde ortaya çıkan atıkların geri dönüşümünü ele almış ve ağı diş sağlı̆̆ merkezlerinde “Geri Dönüşüm” konusunda yeterli çalışmaların olmadığı sonucuna ulaşmıştır.

Kayar 2015 yılında yaptığ1 “Ters Lojistik Sürecinde Karşılaşılan Sorunlar ve Çözümlere İlişkin Nitel Bir Araştırma" adlı nitel araştırmada, örneklem olarak seçtiği işletmelerde ters 
lojistik uygulama nedenlerini ters lojistik kapsaminda yürütülen faaliyetler ve faaliyetler uygulanırken hangi sorunlarla karşılaşıldığını ve ne tür çözümlerin uygulanabileceğini tespit etmeye çalışmıştır. Araştırma sonucunda; işletmelerin ters lojistik faaliyetlerini uygulama nedenlerinin; müşteri memnuniyetini arttırmak, rekabet avantajı sağlamak ve kârı arttırmak olduğunu; işletmelerin ters lojistik uygulama sürecinde en çok depolama, yeniden üretim, atık yönetimi konularının bilinmemesi, pozisyona uygun olmayan tecrübesiz kişiler istihdam etme, ters lojistik kavramının bilinmemesi ve kabul görmemesi konularında sorun yaşandığını tespit etmiştir.

\subsection{Yöntem}

$\mathrm{Bu}$ çalışmada nitel araştırma yöntemi kullanılmıştır. Bu araştırma yöntemi sınırlılıklarına rağmen; kişilerin gerçekçi bakış açılarına ulaşmada ve derinlemesine betimlemede güçlü bir yöntem olduğu için tercih edilmiştir. Araştırmanın veri toplama ve analiz etkinliklerinin amaca uygun şekilde gerçekleştirilmesi ve birbiri ile tutarlı olması için çalışmada nitel araştırma desenleri kullanılmıştır (Yıldırım ve Şimşek, 2008: 47-70).

$\mathrm{Bu}$ araştırma nitel araştırma desenlerinden biri olan olgubilim (fenomenoloji) araştırması olarak desenlenmiştir. Araştırmanın olgusu; "Yeşil Tedarik Zinciri Faaliyetleri ve Yeşil Tedarik Zinciri Kapsamında Tersine Lojistik Faaliyetlerine" ilişkin kazanılmış deneyimlerdir. Bu çalışmada; "Yeşil Tedarik Zinciri Faaliyetleri ve Yeşil Tedarik Zinciri Kapsamında Tersine Lojistik Faaliyetleri" ile ilgili katılımcıların kişisel deneyimlerine ilişkin ayrıntılı veriler toplanmıştır. Mülakata katılan hastane çalışanlarından alınan yanıtlardan yola çıkılarak nihayetinde genel anlamda çıkarımlarda bulunularak derinlemesine bütüncül bir betimleme yapilmıştır.

\subsection{Veri Toplama Süreci}

$\mathrm{Bu}$ çalışmada, veriler ağırlıklı olarak hastanede çalışan kişilerle yüz yüze yapılan görüşmelerden elde edilmiştir. Verilerin bir kısmı ise gözlem ve doküman analizi ile elde edilmiştir. Yüzü yüze yapılan mülakatlar; Denizli ilinde faaliyet gösteren bir hastanenin konuyla ilgili çalışanları ile yürütülmüştür. Bu araştırmada yer alan veriler 2019 yılı içinde toplanmıştır.

Araştırmacının daha sonra başvurduğu hastane yöneticisinin ele alınan konuda daha önceden bireysel olarak ön bilgiye sahip olması yapılan başvuru sürecini kolaylaştırmış ve veri toplamada kolaylık sağlamıştır.

\subsection{Veri Toplama Aracı ve Özellikleri}

$\mathrm{Bu}$ çalışmada; yapılandırılmamış mülakat formu, gözlem, hastanenin web sitesi, hastane belge doküman analizi, araştırmacının hastane ile ilgili kişisel deneyimleri gibi çok boyutlu veri toplama teknikleri kullanılmıştır.

\subsection{Araştırma Sorularının Tanımı}

Araştırmada esneklik tanıyarak zengin, değerli ve derinlemesine veri elde etmede güçlü bir araç olan ve keşfe yönelik açık uçlu sorulardan oluşan; "Yapılandırılmamış Görüşme Yöntemi'ne" göre hazırlanan "Mülakat Formu” kullanılmıştır. 
Mülakat formunda; "Tersine Lojistik Faaliyetlerinin Yeşil Tedarik Zinciri Kapsamında Değerlendirilmesi" ana başlı̆̆ı altında; "Atık Oluşumunun Önlenmesi veya Azaltılması", “Tekrar Kullanım”, "Geri Dönüşüm ve Geri Kazanım”, “Atıkların Muamele Edilmesi ve Nihai Bertaraf" konularına yoğunlaşılmış ve açık uçlu sorulara yer verilmiştir.

\subsection{Vaka Seçimi}

Denizli ilinde faaliyet gösteren bir hastane örneklem olarak seçilmiştir. Görüşme için randevu talep edilmiştir. Araştırmanın verileri üst düzey yöneticiler, satınalma departmanı, eczane hizmetleri birimi ve hastane atık yönetim sorumlulardan elde edilmiştir. Araştırma yapılan hastanenin ismi gizli tutularak "ABC Hastanesi” olarak adlandırılmıştır. 2008 yılında hizmet vermeye başlayan ABC Hastanesi; 40'ın üzerinde hekimi ve 300 personeli; 29 poliklinik, 5 ameliyathane salonu, 32 yataklı yoğun bakım ünitesi, 110 yatak kapasiteli hizmet olanağ 1 ve acil servis birimiyle hizmet vermektedir.

\subsection{Veri Detaylandırma}

Hastane dokümanları, yapılan mülakat formları, web sitesinden alınan bilgiler, yapılan gözlemler bir araya getirilip belirli kategorilere ayrılmıştır. Tutarsızlık durumunda, görüşme yapılan kişilerle mail veya telefon aracılığıyla iletişim kurulup bilgiler güncellenmiştir. Belgelerin kategorileştirilmesinden sonra metinlerin analizi : "“Yeşil Tedarik Zinciri Yönetimi"; "Tersine Lojistik Faaliyetleri"; "Entegre Atık Yönetimi", "Atık Oluşumunun Önlenmesi veya Azaltılması", “Tekrar Kullanma”, “Geri Dönüşüm ve Geri-kazanım”, "Atıkların Muamele Edilmesi ve Nihai Bertarafı" anahtar kelimelerinin kullanılmasıyla gerçekleştirilmiştir.

\subsection{Geçerlilik, Güvenilirlik ve Genelleme}

Araştırmada kullanılan veriler temelde; "Yapılandırılmamış Mülakat Formu" dayanmaktadır. Gözlem formu, hastanene dokümanları, hastane internet sitesi ve araştırmacının kişisel deneyimi mülakat sorularına verilen cevapları destekleyici nitelikte olduğu için değerlendirme kullanılarak çalışmada veri çeşitlemesi yapılmıştır (Yıldırım ve Şimşek, 2008: 77).

Mülakata katılanlar hastanenin; "Yeşil Tedarik Zinciri Kapsaminda Tersine Lojistik Faaliyetlerine" dair sorulan sorulara benzer ve farklı cevaplar vermişlerdir. Sorulara verilen her bir cevapta tutarlılık ve inandırıcılık aranmıştır.

Mülakat formunda yer alan açık uçlu sorulara verilen yanıtların analiz edilmesiyle araştırma sonuçları ortaya çıkmıştır. Mülakat sorularına verilen cevaplar doğrudan alıntı yapılarak aktarılmıştır. Araştırma bulguları ve sonuçlar; katılımcıların onayına sunularak görüşleri alınmış ve bazı noktalarda düzeltmeler yapılmıştır. Birden fazla veri toplama türünün kullanılması sonucu bir kanıt zincirinin oluşturulması araştırmanın yapı geçerliliğini sağlamasına katkıda bulunmaktadır (Yıldırım ve Şimşek, 2008: 289).

\subsection{Araştırma Verilerinin Bulguları ve Değerlendirilmesi}

Araştırmanın bu bölümünde, ABC Hastanesi'nin “Tersine Lojistik Faaliyetlerde Hastane Atıklarının Değerlendirilmesine İlişkin Bulgular" değerlendirilmiştir. Katılımcılara "Atık Oluşumunun Önlenmesi veya Azaltılması", "Tekrar Kullanma”, “Geri Dönüşüm ve Geri- 
kazanım”, “Atıkların Muamele Edilmesi ve Nihai Bertarafı" alt başlıklarıyla toplam otuz altı soru yöneltilmiştir.

\subsection{Tersine Lojistik Faaliyetlerde Hastane Atıklarının Değerlendirilmesine İlişkin Bulgular ve Bulguların Değerlendirilmesi}

ABC Hastanesi'nde tıbbi atık, evsel atık, ambalaj atıkları, cam atık ve tehlikeli atık çeşitleri üretilmektedir. $A B C$ Hastanesinde atık gözlem gününde iki gün sonunda geçici depoda toplanılan tıbbi atık miktarı $402 \mathrm{~kg}$, evsel nitelikte atık miktarı ise 300 torba olmuştur. Katılımcılardan elde edilen bilgilere göre; ABC Hastanesinde 2017 yılında üretilen toplam tehlikeli atık miktarı 4260kg, toplam tıbbi atık miktarı 34263 kg'dır. 2018 yılında üretilen toplam tehlikeli atık miktarı $3658 \mathrm{~kg}$, toplam tıbbi atık miktarı $39.363 \mathrm{~kg}$ 'dır. Hastanede oluşan atık miktarlarının ayrıntılı envanter bilgisine kurum gizliliği sebebi ulaşılamamıştır.

\subsubsection{Atık Oluşumunun Önlenmesi veya Azaltılması}

ABC Hastanesi'nin "Atık Oluşumunun Önlenmesi ve Azaltılması" araştırmak amacıyla katılımcılara; "Kesin Kaçınma/Önleme”, "Kaynağında Azaltılması", “Atıkların Toplanması ve Ambalajlanması", "Atıkların Depolanması" ve "Atıkların Oluşum Yerinden Taşınması" alt başlıkları altında toplam yirmi bir soru yöneltilmiştir.

Atıklardan Kesin Kaçınma/Önleme ile ilgili olarak;

Hastane içerisinde tıbbi ve sarf malzemelerin kullanımı esnasında çevreye verebilecek olumsuz etkileri kontrol eden Sağlık Bakanlığı yasa ve yönetmelikleri uygulanmaktadır. Kan, idrar gibi hasta numuneleri kendilerine özel kutularda toplanmakta ve kendilerine özel kutular ile taşınmaktadır. Bu atıklar tıbbi atık gibi değerlendirilmekte olup atık yönetmeliğine uyulmaktadır. Tıbbi atık yönetimi konusunda hastane içinde enfeksiyon hemşiresi tarafından eğitim verildiği tespit edilmiştir.

Katılımcılar, toksik, korrozif bazı kimyasallar için tehlikeli atık yönetmeliğine uyulduğunu hastaneye özel başka bir uygulamanın olmadığını, enfekte atıkların atık yönetmeliği gereğince farklı lavobalara dökülmediğini, radyolojik görüntüleme süreçlerinde kullanılan tehlikeli (X-ray vs.) atık türünün kurşun olduğunu ancak kurumda hematoloji ve radyoloji bölümü olmadığı için çok fazla kurşun atık üretilmediğini belirtmişlerdir. Tehlikeli atık biriminde çalışan personellere tehlike madde ve riskleri hakkında eğitim hemşiresi tarafından gerekli eğitimin verildiği belirlenmiştir.

Hastane içi atık yönetim konusunda eğitim verilmekte ancak verilen eğitimler genellikle temizlik elemanlarını kapsamaktadır. ABC Hastanesi'nde, Sağlık Bakanlığı yasa ve yönetmelikleri dışında bir atıklardan kaçınmak ve önlenmesi için bir mekanizma mevcut değildir.

\section{Atıkların Kaynağında Azaltılması ile ilgili olarak;}

Hastane, kimyasal temizlik malzeme çeşitlerinin doğru ve yerinde kullanımı için her katta depo oluşturarak temizlik malzemelerinin kontrollü kullanımını sağlamaktadır. Kullanımda ölçü kabı kullanılmakta ve zaman zaman temizlik şefi tarafından kontrol amaçlı depolara habersiz vizit yapılmaktadır. Hastane içinde oluşan batarya pil atıkları, hastane içinde belirlenen bir bölümde biriktirilmekte olup, hastane "Boşunu Getir Dolusunu Al” sloganı ile 
batarya gereksinimlerini karşılamaktadır. Bu faaliyetlerin kontrol edilme amacının atık azaltmak değil, maliyetleri minimize etmek olduğu katılımcılar tarafından belirtilmiştir.

Hastanede atıkları kaynağında en aza indirmek için, yönetmelikte belirtilen şekilde atıkların kaynağında ayrıştırılmasına dikkat edilmektedir. Hastane atık kutularının üzerinde büyük yazılarla açıklama ve yönlendirmeleri ile birlikte atık isimleri yazılmıştır. Atıkların ayrılmasında atıkların oluşacağı alanlarda hastane farkındalık ve duyarlılık yaratmak amacıyla renkli çöp kutuları kullanmayı tercih etmiş ve kutuların üzerine büyük harflerle bilgilendirme yazılmıştır.

Atık torbaları birimlerden toplanırken üzerine atık etiketi yapıştırılarak hangi birimden alındığı not edilmekte ve lisanslı firma atıkların etiketlerini kontrol ederek birim bazında atık deposunda tartarak teslim almaktadır. Teslim edilen atık miktarı Sağlık Bilgi Yönetim Sisteminde (SBYS) oluşturulan "Atık Modülüne" kaydedilmektedir. Eğer birimlerde atıkların yanlış atık kutusuna atıldığı tespit edilirse duyarsızlık haline neden olan çalışan tespit edilerek uyarı cezası verilmekte ve tutanak tutulmaktadır.

$\mathrm{Bu}$ durum hastanenin atıkların kaynağında ayrıştırılması ve azaltılması konusunun atık yönetmeliği gereğince etkin uygulandığını göstermektedir.

Atıkların Toplanması ve Ambalajlanması ile ilgili olarak;

Atıkların ayrılmasında atıkların oluşacağı alanlarda hastane farkındalık ve duyarlılık yaratmak amacıyla atık kutularını renkli kullanmayı tercih etmiş ve kutuların üzerine büyük harflerle bilgilendirme yazılmıştır. Evsel nitelikli atıklar, ambalaj atıkları, tıbbi atıklar, tehlikeli atıklar ve radyoaktif atıklar kaynağında ayrı ayrı toplanmaktadır. Atık kutuları günde 2 kez rutin olarak boşaltılmaktadır. 4/3 nün dolması durumunda hemen boşaltılmaktadır. Çevreye zarar verici koku, enfeksiyon, delinme yırtılma durumlarında hemen boşaltılmaktadır.

Atıkların kaynağında ayrı toplanması için hangi atıkların hangi kutuya atılması gerektiği konusunda yönlendirmeler ve yeterli açılamalar mevcuttur. Bu durum hastane yönetimi tarafından hastane içinde atık yönetimi ile ilgili bilgilendirme yapılmış olduğunun göstergesidir. Anacak, tıbbi atıklar hastane içinde toplanırken ve taşınırken; hastaların kullandığı asansörlerde hastalarla birlikte taşınmakta olup, atık torbaları servislerden alınırken ağzı bağlanmamakta ve konteynerın kapağı görevli tarafından rasgele toplu alanlarda açılarak konteynır içi düzenleme yapılmaktadır. Görevli tarafından konteynırın hastane içinde rasgele açılarak poşetlerin düzenlenmesi, hastane çalışanları ile hastaların sağlığı açısından enfeksiyon riski oluşturmaktadır. Bu davranış, personelin tıbbi atıkların toplanması ve ambalajlanması konusunda yeterince bilinçli olmadığını ortaya koyarken, hastane içi atık yönetimi konusunda denetim eksikliği olduğunu göstermektedir.

\section{Atıkların Depolanmast ile ilgili olarak;}

Hastanenin, büyüklüğüne ve atık kapasitesine uygun boyut ve niteliklere sahip konteyner ve geçici atık deposuna sahip olduğu gözlemlenmiştir. Katılımcılar atık depolama prosedürleri ilgili personele eğitim hemşiresi tarafından belirli aralıklarla eğitim verildiğini belirtmişlerdir. 
Depoda bulunan atıkların türlerine göre maksimum bekleme süreleri atık sorumluları tarafından bilinmektedir. Evsel atıklar: belediye tarafından her gün belirli saatlerde alınmaktadır. Tehlikeli atıklar: 3-6 ay arasında anlaşmalı firma tarafından alınmaktadır. Tıbbi atıklar; Pazartesi, Çarşamba ve Cuma günleri lisanslı firma tarafından geçici depodan alınmaktadır. Geçici atık depolama alanı gerektikçe ve haftada 3 gün dezenfekte edilmektedir. Geçici atık deposu su ile yıkanılarak değil silinerek dezenfekte edildiği için depoda drenaj sistemi mevcut değildir. Atıklardan akan sıvıların etrafa yayılmasını engellemek amacıyla depo tabanı silindikten sonra talaşlanmakta ve her temizlikte talaşlar değiştirilmektedir. Hastanenin geçici atık depolarında drenaj sistemi kullanmak yerine, geçici atık deposunun sızıntı sularının talaşla yoğurarak tıbbi atık torbasına dâhil edilmesi, enfekte atık kirli sularının kanalizasyona karışmasını engellemektedir.

Hastanede de onkoloji ve hematoloji bölümü mevcut olmadığı için radyolojik atık üretilmediği tespit edilmiştir.

Atıkların Oluşum Yerinden Taşınması ile ilgili olarak;

Atıkların toplanması ve taşınmasında görevli personelin giymesi gereken turuncu tulum, gözlük, çizme, maske ve eldiven mevcut olup bu konuda eğitimli iki personel bulunmaktadır. Atıkların toplanması ve taşınması sırasında kullanılacak personel kıyafetleri için hastane dışında, atık taşıma konteynırlarının depolandığı alanda bir soyunma kabini mevcut olup, kıyafetlerin burada muhafaza edildiği gözlemlenmiştir.

Görevli personel atıkların toplanması ve geçici atık deposuna taşınması sırasında oluşabilecek kazalara karşı alınacak önlemlerin eğitim hemşiresi tarafından anlatıldığını dile getirmiştir.

\subsubsection{Tekrar Kullanma}

Hastanede Sağlık Bakanlığı tarafından belirtilen tekrar kullanımı mümkün malzemelere (plastik hariç) tekrar kullanılmadan önce talimatlara uygun şekilde otoklav ve strelizasyon işlemi uygunlanmaktdır. Katılımcılar hastanede sterilize edilerek tekrar kullanımımı mümkün malzeme sayısının belirtilenden daha fazla olduğunu, ancak Sağlık Bakanlığg'nın öngördüğü yasal zorunluluklardan dolayı bu sayının daha düşük olduğunu belirtmişlerdir. Örnek olarak Damar mühürleme de kullanılan LigaSure malzemesi gösterilmiştir. Geçmiş yıllarda LigaSure tıbbi malzemesinin tek kullanımlık tıbbi malzemelerden olduğu ancak daha sonra Sağlık Bakanlığı tarafından tekrar kullanımı mümkün olmayan malzemeler arasına alındığını ve bu sebeple bu tıbbi malzemenin yasal zorunluluktan dolayı artık tekrar kullanımının mümkün olmadığı dile getirilmiştir. Bu duruma paralel olarak literatür incelediğinde; ülkemiz dışında bazı ülkelerde LigaSure malzemesinin tekrar kullanımının yaygın olduğu görülmüştür. Makay vd. (2017), tek kullanıma uygun olduğu bildirilen damar mühürleme sisteminin tekrar kullanımlarının komplikasyon oranlarına etkilerini irdelemek amacıyla hastalar üzerinde yaptıkları akademik çalışmada; tek kullanımlık olduğu bildirilen LigaSure tıbbi malzemesinin titizlikle yapılan sterilizasyon işlemleri sonucunda tekrar kullanımının herhangi bir komplikasyon oluşturmayacağı sonucuna ulaşmışlardır. Bu örnek doğrultusunda, ABC Hastanesinin yaygın olarak tekrar kullanımda bulunmama nedenlerinin başında yasal zorunluluklar gelmektedir. 
Hastane, hasta ve personelin kullandığı ameliyathane kıyafetlerinde tek kullanımlık kıyafetler yerine sterilize edilebilir kıyafetleri tercih etmektedir. Hastane strelizasyon işlemleri hizmet satın alma yoluyla karşılanmaktadır. Strelizasyon işlemleri satın alma yoluyla yapıldığı için hastanede, kirli malzeme girişi ve kirli depo ile steril malzeme çıkış ve steril depo bölümleri bulunmaktadır. Gerçekleştirilen işlemler sonunda enfekte olmuş ameliyat giysi ve ekipmanlar hemen toplanarak sterilize edilmeye ve yıkamaya gönderilmektedir. Enfekte olmuş ameliyat giysilerinin personel ve hastalar ile temasını önlemek amaçlı çuval paketleme sistemi kullanılmakta olup kullanılan çuvallar tekrar kullanima uygundur.

\subsubsection{Geri Dönüşüm ve Geri Kazanım}

Hastane kullandığı malzeme ve ekipmanlarla ilgili yönetmeliklerde belirtilen geri dönüşüm ve geri kazanım faaliyetlerini uygulamaktadır.

Katılımcılar hastanede geri kazanılabilir atık olarak sadece kâğıt kullanımının minimize edilmesi konusunda bir uygulama başlatıldığını ancak çalışanların duyarlılık göstermemesi üzerine uygulamanın başarılı olmadığını dile getirmişlerdir. Mevcut hastane atık yönetim planı incelendiğinde geri dönüşebilir ve geri kazanılabilir atık kavramına, tıbbi atık ve evsel atıklara göre daha soyut bakıldığı tespit edilmiştir. Hastanede tıbbi atıklar toplanırken gösterilen duyarlılığın geri dönüşebilir ve geri kazanılabilir atıklar toplanırken gösterilmediği gözlemlenmiştir. Katılımcılar, sadece hastane yazıcılarda kullanılan tonerlerin boş kaplarını tedarik edilen firmaya tekrar kullanılmak üzere teslim edildiğini belirtmişler; kullanılmış, ömrünü tamamlayarak hurda haline gelmiş demirbaş malzemelerin, geri dönüşümü için herhangi bir yöntem izlenmediğini ve bu malzemelerin toplanarak hastane deposunda bekletildiğini belirtmişlerdir.

Mevcut durum incelendiğinde; Sağlık Bakanlığ tarafından belirlenen prosedür ve yönetmelikler dışında; hastane bünyesinde geri kazanım ve geri dönüşümü yapılabilecek ürünlerin bilinçli olarak tespit edilip değerlendirilmesini sağlayan bir uygulamanın mevcut olmadığı sonucuna ulaşılmıştır. Hastanede geri kazanım ve geri dönüşümün teşvik edilerek, bu konuda bir uygulamanın başlatılması, kullanılmış, ömrünü tamamlayarak hurda haline gelmiş demirbaş malzemelerin değerlendirilmesini sağlayacaktır.

\subsubsection{Atıkların Muamele Edilmesi ve Bertarafı}

Hastane tıbbi atıkları Denizli ilinde bulunan lisanslı tıbbi atık bertaraf tesisine teslim edilmektedir. Atık tesliminde lisanslı firmadan doldurulmuş atık taşıma formu alınmaktadır. $\mathrm{Bu}$ formun bir örneği hastanede, diğer örneği lisanlı firmada kalmaktadır. Depolanan tıbbi atıkların nihai bertaraf işlemi için kuruma teslim süresi; Pazartesi, Çarşamba ve Cuma olmak üzere haftada üç gündür. Tıbbi atıkların hafta üç gün lisanslı firma tarafından alınması, atık deposunun taşmasını ve atıkların yı̆̆ılarak sıkışmasını engellemektedir.

ABC Hastanesi geçici deposunda bulunan tıbbi atıkları bertaraf etmek için teslim almaya gelen Denizli ilinde faaliyet gösteren tıbbi atık bertaraf firmasının çalışanlarından süreç hakkında bilgi alınmıştır. Denizli ilinde bulunan tıbbi atıkların nihai bertaraf işlemi yakma işlemi kullanmadan, sterilizasyon işlemi ile gerçekleştirilmektedir. Sterilizasyon işlemine tabi tutulan tıbbi atıkların zararsız hale getirilip getirilmediği, kimyasal ve biyolojik indikatörler kullanılarak test edilmektedir. Eğer test sonucu negatif çıkarsa atıklar tekrar sterilize 
edilmektedir. Steril olan atıklar ise nihai bertaraf için düzenli depolama sahasına götürülmektedir.

Hastane tehlikeli atıkları, Kocaeli ilinde bulunan; "Tehlikeli Atık Yakma Tesisine" gönderilmektedir. Katılımcılar Türkiye'de, biri İstanbul diğeri Kocaeli'nde olmak üzere iki tıbbi atık yakma tesisi bulunduğunu ve konum itibari ile İzmit Büyükşehir Belediyesi İzmit Atık ve Artıkların Arıtma ve Yakma Değerlendirme A.Ş. (IZZAYDAŞ) tercih ettiklerini belirtmişlerdir.

Evsel atıklar günlük olarak, Denizli Büyükşehir Belediyesi tarafından toplanmaktadır. Ambalaj atıkları ise geçici depoda depolanmakta ve geçici deponun atık doluluk durumuna göre yetkili firmaya haber verilerek ambalaj atıkları deposu boşaltılmaktadır.

Katılımcılar, "Atıkların Muamele Edilmesi ve Bertarafı" konusunda lisanslı firma sayısı az olduğu için seçme haklarının olmadığını, firmaların tekel olmasının maliyetleri arttırdığını belirtmişlerdir.

ABC Hastanesinde yönetmelikler dışında, atık azaltılması, atıkların yeniden kullanımı ve geri dönüşümünü sağlayan herhangi bir tıbbi atık yönetim metodu uygulanmamaktadır.

\section{SONUÇ}

Atıkların geçici depolanması, kaynağında ayrıştırılarak azaltılması tersine lojistik faaliyetler yönetmelikler doğrultusunda gerçekleştirilmeye çalışılmaktadır. Ancak, atıkların kaynağında toplanması konusunda etkin bir denetim mekanizması mevut olmayıp, atıkların kaynağında azaltılması konusunda ise atıkların yönetmeliklerde belirtilen poşetlere ayrıştırılarak toplanması dışında teşvik edici herhangi bir çalışmanın varlığı söz konusu değildir. Hastane atıklarının kaynağında azalmasını sağlamak amacıyla; hastane içinde atık yönetiminin etkililiği ve hastane çevre bilincinin arttırılabilmesi için çeşitli uygulamalara daha geniş yer verilmesi gerekmektedir.

Hastanelerin atık yönetimi konusunda yönetmelikler olmasına rağmen hastane yönetiminin ve hastane çalışanlarının atık yönetimi ve çevre konusunda bilinçli olmaması, hastane içinde etkin bir otorite ve denetimin olmaması hastane içi atık yönetiminin gerektiği gibi yapılmamasına, hastanelerin tıbbi atık yönetim konusunda başarısız olmasına neden olmaktadır. Aydemir'in (2017) atık üretimi, atıkların kurum içinde ve dişında yönetim süreçleri, atıkların sağlık üzerindeki olası etkileri ile atık minimizasyonu doğrultusunda atık piramidini değerlendirmek amacıyla yaptığı çalışmada; hastanelerde entegre atık yönetiminde bulunan kaçınma ve önleme ile hedeflenenin atıkların minimize edilmesi olduğuna değinmiş ve atıkların önlenmesi yoluyla hastanelerde kaynak tasarrufu, verimlilik ve maliyet etkililiği sağlanacağını belirtmiştir. Hastanede maliyet etkililiğini ve verimliliği arttırmak, kaynak tasarrufu ve başarılı bir entegre atık yönetimi ile çevre bilincinin oluşturulmasını sağlamak için sosyal sorumluluk projesi başlatılması önerilebilir. Oluşturulan proje kapsamında ABC Hastanesi'nde bir çevre ekibi kurulabilir.

$\mathrm{Bu}$ çalışma ile tersine lojistik faaliyetlerin hastanelerin atık yönetimindeki önemi ve bu süreçte dikkat edilmesi gereken hususlar ortaya konulmaya çalışılmıştır. Ancak, yapılan araştırma sonucunda tersine lojistik faaliyetlerinin maliyeti artıran, ek maliyet gerektiren ve verimsiz uygulamalar olarak görüldü̆ğü, atıkların ayrıştırılması, azaltılması, toplanması, geri 
dönüşümü gibi tersine lojistik faaliyetlerin yönetmeliklerin getirdiği zorunluluklar dâhilinde gerçekleştirildiği sonucuna ulaşılmıştır.

\section{KAYNAKÇA}

Aydemir, İ. (2017). Türkiye'de Çevre Bilinci Kapsamında Tıbbi Atık Üretim Süreçleri ve Yönetimi, Bingöl Üniversitesi Sosyal Bilimler Enstitüsü Dergisi, Yıl: 7, 7(13).

Baylan, A. (2009). Tıbbi Atıkların Bertarafı Üzerine Çalışma Edirne Örneği, Yüksek Lisans Tezi, Namık Kemal Üniversitesi, Fen Bilimleri Enstitüsü, Tekirdağ.

Baş, T. ve Akturan, U. (2008). Nitel Araştırma Yöntemleri, NVivo 7.0 ile Nitel Veri Analizi, 1. Baskı, Seçkin Yayıncılık, Ankara.

Demirel, H.Ö. ve Gökçen, H. (2008). Geri Kazanımlı İmalat Sistemleri İçin Lojistik Ağ1 Tasarımı: Literatür Araştırması, Gazi Üniv. Müh. Mim. Fak. Der., 23-4, 903912.

Dündar, E. (2010). Hastane Atıklarının Yönetiminde Geri Kazanilabilir Atik Miktarlarının Tesbiti Ve Ekonomik Değeri Ankara Örneği, Yüksek Lisans Tezi, Gazi Üniversitesi Fen Bilimleri Enstitüsü, Ankara.

e-Mevzuat, (2002). Özel Hastaneler yönetmeliği, Mevzuat bilgi sistemi, Resmî Gazete Tarihi: 27.03.2002 Resmî Gazete 24708. http://www.mevzuat.gov.tr/Metin.Aspx?MevzuatKod=7.5.4854\&Mevzuatlliski=0\&so urceXmlSearch=\%C3\%B6zel\%20hastane (Erişim Tarihi: 20.04.2019).

Eltayeb, T.K., Zailani, S., Ramayah, T. (2010). Green Supply Chain İnitiatives Among Certified Companies in Malaysia and Environmental Sustainability: Investigating the Outcomes, Resources, Conservation, Recycling.

Erdal, M., Görçün, Ö.F., Görçün, Ö. ve Saygıll, M.S. (2010). Entegre Lojistik Yönetimi, Beta Yayınları 2. Baskı, Aralık 2010 , İstanbul.

Erkayman, B. (2007). Lojistikte Taşıma Şekillerinin Belirlenmesi, Yayınlanmamış Yüksek Lisans Tezi, Yıldız Teknik Üniversitesi Fen Bilimleri Enstitüsü, İstanbul.

Ege, H. ve Budak, F. (2012). Adana İli Tıbbi Atık Yönetimi; Sorunlar Ve Çözüm Önerileri, Ç.Ü Fen ve Mühendislik Bilimleri Dergisi, Y11:2012 Cilt:27-5.

Ferraz A., Barcelos C.B. ve Pontes R. (2000). Concentration Of Atmospheric Pollutants In The Gaseous Emissions Of Medical Waste Incinerators, Journal of The Air $\mathcal{E}$ Waste Management Association, 50, 131-136.

Fritsky, K. J., Kumm, J. H. ve Wilken, M. (2001). Combine PCDD/F Destruction and Particulate Control In A Baghouse: Experience With A Catalytic Filter System At A Medical Waste Incineration Plant, Journal of The Air $\mathcal{E}$ Waste Management Association, $51,1642-1649$.

Fleischmann, M. ve Beullens, P., Bloemhof-Ruwaard J.M., Van, Wassenhove, L.N. (2001). The Impact of Product Recovery on Logistics Network Design, Production and Operations Management, 10, 156. 
Fleischmann, M., Bloemhof-Ruwaard, J.M., Dekker, R., Van Der Laan, E., Van Nunen, J.A.E.E. ve Van Wassenhove, L.N. (1997). Quantitative Models For Reverse Logistics: A Review (Invited Review), European Journal of Operational Research, 103, 1-17.

Gündüzalp, A.A. ve Güven, S. (2016). Atık, Çeşitleri, Atık Yönetimi, Geri Dönüşüm ve Tüketici: Çankaya Belediyesi ve Semt Tüketicileri Örneği, Hacettepe Üniversitesi Sosyolojik Araştırmalar E-Dergisi, s.1-19, Ankara.

Johnson, P. (1998). Managing Value in Reverse Logistics Systems, Logistics and Transpn Rewiev, 34(3), 217-227.

Kamu İhale Mevzuatı, https://Www.İhale.Gov.Tr/Mevzuat.Aspx (Erişim Tarihi: 16.02.2018)

Kaya, T. (2016). Diş Tedavi Merkezlerinde Tıbbi Atık Yönetimi, Yüksek Lisans Tezi, İzmir Kâtip Çelebi Üniversitesi, Sağlık Bilimleri Enstitüsü, Hemşirelik Anabilim Dalı, İzmir.

Kayar, Y. (2015). Ters Lojistik Sürecinde Karşılaşılan Sorunlar ve Çözümlere İlişkin Nitel Bir Araştırma, Yüksek Lisans Tezi, Namık Kemal Üniversitesi Sosyal Bilimler Enstitüsü İşletme Anabilim Dalı, Tekirdağ.

Kokulu, D. (2001). Tıbbi Atık Yönetimi ve Mevzuattaki Yeri, 1. Ulusal Katı Atık Kongresi (UKAK 2001), 18-21 Nisan, İzmir.

Laustsen, G. (2007), Reduce-recycle-reuse: Guidelines for Promoting Perioperative Waste Management, Aorn Journal, 85(4), 717-728.

Lee, B.K., Ellenbecker, M.J. ve Moure-Ersaso, R. (2004). Alternatives For Treatment And Disposal Cost Reduction Of Regulated Medical Wastes, Waste Management, 24, 143151.

Lee, A.H.I., Kang, H.Y., Hsu, C.F., Hung, H.C. (2009). A Green Supplier Selection Model For High-Tech İndustry, Expert Systems with Applications, 36, 79177927.

Lee, H.L. ve Billingtion, C. (1992). Managing Supply Chain Inventory: Pitfalls and Opportunities, Sloan e-Management Review, Vol.33, No:3, pp:65-73.

Makay, Ö., İçöz, G., Akyıldız, M., Yılmaz, M. ve Yetkin, E. (2017). Tiroit Cerrahisinde Tek Kullanımlık LIGASURE Damar Mühürleme Sisteminin Çoklu Kullanımı Komplikasyon Oranlarını Arttırıyor Mu?, 21. Ulusal Cerrahi Kongresi, s.:31, 11-15 Nisan, Antalya.

Öktem, B. (2016). Atık Yönetiminde Entegre Uygulama, Batman Üniversitesi, Yaşam Bilimleri Dergisi, Cilt:6, Sayı 2/1.

Özkan, O., Bayın, G. ve Yeşilaydın, G. (2015). Sağlık Kurumlarında Sürdürülebilir Atık Yönetimi, 2nd International Sustainable Buildings Symposium, 28 - 30 Mayıs 2015, Gazi Üniversitesi, Ankara.

Özkan, O., Bayın, G. ve Yeşilaydın, G. (2015). Sağlık Sektöründe Yalın Tedarik Zinciri Yönetimi, AJIT-e:Online, Academic Journal of Information Technology, Cilt:6- Say1:18, s.71-94

Parker, D.(2010). Briefing: Remanufacturing and Reuse- trends and prospects, Waste and Resource Management, Vol: 163, Issue:4, Kasim, pp.141-147. 
Rogers, D. ve Tibben R.S. (2001). An Examination Of Reverse Logistics Practices, Journal Of Business Logistics, 22, 129-147.

Sağlık Mevzuatı, (2016). https://www.saglik.gov.tr/TR,10357/saglik-mevzuati.html (Erişim Tarihi: 16.01 .2018$)$

Terekli, G., Özkan, O. ve Bayın, G. (2013). Çevre Dostu Hastaneler: Hastaneden Yeşil Hastaneye, Sağlık Hizmetleri Dergisi, 12 (2): 37, Ankara.

Tibben-Lembke, R.S. ve Rogers, D.S. (2002). Differences Between Forward and Reverse Logistics in a Retail Environment, Supply Chain Management: An International Journal, $7(5), 271-282$.

Türkiye İstatistik Kurumu (TÜİK). (2017), 24877 sayılı atık Bertaraf ve Geri Kazanım Tesisleri İstatistikleri,. http://www.tuik.gov.tr/PreTabloArama.do?metod=search\&araType=hb_x (Erişim Tarihi: 22.02.2018).

Yıldırım, A. ve Şimşek, H. (2008). Sosyal Bilimlerde Nitel Araştırma Yöntemleri, 6.Baskı, Seçkin Kitapevi, Ankara.

Yönetmelik,(2005). Tehlikeli Atıkların Kontrolü Yönetmeliği, Resmi Gazete, http://www.resmigazete.gov.tr/eskiler/2005/03/20050314-1.htm (Erişim Tarihi: 20.01.2019).

Yönetmelik,(2017). Tıbbi Atıkların Kontrolü Yönetmeliği, Resmi Gazete, 25/01/2017,Say1:29959, http://www.resmigazete.gov.tr/eskiler/2017/01/20170125-2.htm (Erişim Tarihi: 04.02.2019).

Yönetmelik,(2015). Atık Yönetimi Yönetmeliği, Resmi Gazete, 02/04/2015,Sayı:29314, http://www.resmigazete.gov.tr/eskiler/2015/04/20150402-2.htm (Erişim Tarihi: 18.02.2019).

İSTAÇ, İstanbul Çevre Yönetimi San. ve Tic.A.Ş., https://www.istac.istanbul/contents/1318/YEN\%C4\%B0\%20tehlikeli\%20at\%C4\%B1k_ 14_12_16.pdf(Erişim Tarihi:26.02.2019).

${ }^{2}$ http://www.izmiralternatif.com.tr/haberdetay/atik-hiyerarsisi/ (Erişim Tarihi: 26.02.2019). 